\title{
Contact-haemolysin production by entero-invasive Escherichia coli and shigellae
}

\author{
KHALEDA HAIDER, M. J. ALBERT, A. HOSSAIN* and S. NAHAR
}

Laboratory Sciences Division, International Centre for Diarrhoeal Disease Research, GPO Box 128, Dhaka 1000, and - Department of Microbiology, University of Dhaka, Dhaka 1000, Bangladesh

\begin{abstract}
Summary. Entero-invasive Escherichia coli (EIEC) and shigellae were tested for contacthaemolysin $(\mathrm{CH})$ with red blood cells (RBCs) of guinea-pig, rabbit, rat, mouse, monkey, man, sheep and chicken; all bacteria showed the best lysis with guinea-pig RBCs. The best culture medium for $\mathrm{CH}$ activity of shigellae was tryptic soy broth, and for EIEC it was casamino acid-yeast extract broth with $1 \mathrm{mM} \mathrm{CaCl} 2 . \mathrm{CH}$ production by all species was best at the slightly alkaline $\mathrm{pH}$ which is optimal for growth; it was also dependent on the presence of a large (140-Mda) plasmid. Pre-treatment of bacteria with homologous antisera inhibited $\mathrm{CH}$ activity. Various treatments of bacterial cells and $\mathrm{RBCs}$ suggested that $\mathrm{CH}$ may be a protein molecule, and that a chitotriose-like moiety may serve as $\mathrm{CH}$ receptor. $\mathrm{RBCs}$ that were incubated with bacteria at $4^{\circ} \mathrm{C}$, or with heat-killed bacteria at $37^{\circ} \mathrm{C}$, were not lysed; also, isolated cell-surface components (lipopolysaccharide and outer-membrane protein) did not lyse RBCs. This suggests that metabolically active cells are required for $\mathrm{CH}$ activity. Production of $\mathrm{CH}$ by both EIEC and shigellae is consistent with a common mechanism for the virulence of these organisms.
\end{abstract}

\section{Introduction}

Disease caused by shigellae involves a complex process of invasion and multiplication in the mucosa of the human colon. ${ }^{1}$ The process of invasion requires entry of the bacterium into the enterocytes, and lysis of the membranous vacuole which surrounds it after invasion, to allow free multiplication of the pathogen within the cytoplasm. This leads to spread of the organisms to the lamina propria, triggering a severe inflammatory response in the gut mucosa with abscesses and ulceration. ${ }^{2,3}$ All these features are regulated by a large non-self-conjugative plasmid of 120-140 Mda called the virulence plasmid. Enteroinvasive Escherichia coli (EIEC) produces dysentery like that caused by shigellae; it also possesses a 140Mda plasmid which is associated with virulence. ${ }^{4,5}$

Sansonetti et al. ${ }^{6}$ described a virulence-plasmidmediated, thermoregulated contact-haemolysin $(\mathrm{CH})$ in Shigella, which was active against sheep red blood cells (SRBC). Close contact was required between virulent bacteria and SRBC which was achieved by centrifugation. The production of $\mathrm{CH}$ correlated with its capacity to destroy the membranous vacuole surrounding the bacteria after invasion of HeLa cells, and with efficient intracellular multiplication. $\mathrm{CH}$ was also demonstrated in $S$. dysenteriae and $S$. sonnei strains in another study. ${ }^{7}$

Received 19 Dec. 1990; revised version accepted 3 April 1991
The large virulence-plasmids of EIEC and all species of Shigella have extensive homologous sequences and are functionally exchangeable. ${ }^{8}$ As the pathogenesis of EIEC and Shigella spp. is similar, this study was initiated to investigate whether $\mathrm{CH}$ was also produced by $S$. boydii and EIEC, other species of Shigella being included for comparison. Factors influencing the production and activity of $\mathrm{CH}$ were investigated by the use of virulent and avirulent pairs. Preliminary experiments were also performed to study the chemical nature of $\mathrm{CH}$.

\section{Materials and methods}

\section{Bacterial strains and culture conditions}

The bacterial strains are shown in table I. Dr D. N. Taylor, Armed Forces Research Institute of Medical Sciences (AFRIMS), Bangkok, kindly provided 26 strains of EIEC from patients with invasive diarrhoea in Thailand. Five similar isolates were from central Australia (2), Bangladesh (2) and Hungary (1). ${ }^{9}$ The avirulent EIEC strain 2/33 is an isogenic mutant strain of virulent EIEC strain 2, isolated in Hungary $;{ }^{9}$ these were kindly supplied by Dr P. Echeverria (AFRIMS, Bangkok). E. coli strain 36000 was obtained from the Centers for Disease Control, Atlanta, GA, USA. All Shigella strains were isolated from patients at the Clinical Research Centre, International Centre for Diarrhoeal Disease Research, Bangladesh. The $\mathrm{CH}$ 
Table I. $\mathrm{CH}$ activity and HeLa-cell invasiveness of shigellae and EIEC

\begin{tabular}{|c|c|c|c|c|c|}
\hline \multicolumn{3}{|c|}{ Organism } & $\begin{array}{l}\text { Number of } \\
\text { strains }\end{array}$ & $\begin{array}{c}\text { CH activity } \\
\left(\mathrm{OD}_{490}\right)\end{array}$ & $\begin{array}{c}\text { Number* of } \\
\text { bacteria/HeLa cell }\end{array}$ \\
\hline \multicolumn{2}{|c|}{$\begin{array}{l}\text { S. dysenteriae } \\
\text { type } 1\end{array}$} & $\begin{array}{l}\text { Virulent } \\
\text { Avirulent } \\
\text { Rough }\end{array}$ & $\begin{array}{l}5 \\
5 \\
4\end{array}$ & $\begin{array}{l}2 \cdot 19 \\
0 \cdot 89 \\
0 \cdot 12\end{array}$ & $\begin{array}{r}53 \\
0 \\
0\end{array}$ \\
\hline \multicolumn{2}{|l|}{ S. sonnei } & $\begin{array}{l}\text { Virulent } \\
\text { Avirulent } \\
\text { Rough }\end{array}$ & $\begin{array}{l}5 \\
5 \\
4\end{array}$ & $\begin{array}{l}1 \cdot 65 \\
0 \cdot 12 \\
0 \cdot 15\end{array}$ & $\begin{array}{r}54 \\
0 \\
0\end{array}$ \\
\hline \multicolumn{2}{|l|}{ S. boydii } & $\begin{array}{l}\text { Virulent } \\
\text { Avirulent }\end{array}$ & $\begin{array}{l}5 \\
5\end{array}$ & $\begin{array}{l}1 \cdot 16 \\
0 \cdot 34\end{array}$ & $\begin{array}{r}11 \\
0\end{array}$ \\
\hline S. flexner & 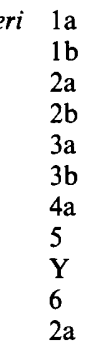 & $\begin{array}{l}\text { Virulent } \\
\text { Virulent } \\
\text { Virulent } \\
\text { Virulent } \\
\text { Virulent } \\
\text { Virulent } \\
\text { Virulent } \\
\text { Virulent } \\
\text { Virulent } \\
\text { Virulent } \\
\text { Avirulent }\end{array}$ & $\begin{array}{l}2 \\
2 \\
5 \\
2 \\
2 \\
2 \\
1 \\
2 \\
2 \\
2 \\
5\end{array}$ & $\begin{array}{l}1.06 \\
0.72 \\
2 \cdot 43 \\
0.71 \\
1 \cdot 10 \\
1 \cdot 14 \\
1 \cdot 10 \\
2.00 \\
2.27 \\
1 \cdot 44 \\
0.51\end{array}$ & $\begin{array}{r}25 \\
5 \\
70 \\
3 \\
15 \\
15 \\
12 \\
51 \\
65 \\
20 \\
0\end{array}$ \\
\hline EIEC & $\begin{array}{r}\text { O28 } \\
\text { O29 } \\
\text { O143 } \\
\text { O144 } \\
\text { O164 } \\
\text { O124 } \\
\text { O136 } \\
\text { O143 }\end{array}$ & $\begin{array}{l}\text { Virulent } \\
\text { Virulent } \\
\text { Virulent } \\
\text { Virulent } \\
\text { Virulent } \\
\text { Virulent } \\
\text { Virulent } \\
\text { Avirulent }\end{array}$ & $\begin{array}{r}24 \\
2 \\
1 \\
1 \\
1 \\
1 \\
1 \\
1\end{array}$ & $\begin{array}{l}2.72 \\
1.35 \\
0.87 \\
0.82 \\
0.90 \\
0.56 \\
1.01 \\
0.50\end{array}$ & $\begin{array}{r}152 \\
15 \\
3 \\
6 \\
6 \\
4 \\
27 \\
0\end{array}$ \\
\hline E. coli & 36000 & Avirulent & 1 & $0 \cdot 10$ & 0 \\
\hline
\end{tabular}

* Each of these numbers is the approximate mean of results from at least three experiments.

Virulent strains gave a positive Sereny result, invaded HeLa-cells and bound Congo red dye; avirulent strains did none of these. Virulent strains had a 120-140-Mda virulence plasmid; avirulent strains had either no virulence plasmid or a deleted one. Rough strains autoagglutinated in physiological saline and did not have the virulence plasmid.

activity of bacterial components was studied with $S$. flexneri strain Z-611, S. dysenteriae type 1 strain Z24623, and EIEC strain 2.

All the strains were stored at $-70^{\circ} \mathrm{C}$ in Trypticase Soy Broth containing yeast extract $0.6 \% \mathrm{w} / \mathrm{v}$ (TSB; Gibco) with glycerine $15 \% \mathrm{v} / \mathrm{v}$. The growth media were TSB, Casamino Acid-Yeast Extract Broth (Difco) supplemented with $1 \mathrm{mM}$ calcium chloride (CYE) and minimal medium (MM) as described by Ahmed $e$ al. ${ }^{10}$

\section{Assay of $\mathrm{CH}$}

$\mathrm{CH}$ activity was measured by the method of Sansonetti et al. ${ }^{6}$ Briefly, bacteria were washed once and suspended in phosphate-buffered saline $\mathrm{pH} 7 \cdot 3$ (PBS) to a concentration of $2 \times 10^{10} \mathrm{cfu} / \mathrm{ml}$; blood was collected in Alsever's solution, washed twice, and the packed RBCs were resuspended in PBS to a concentration of $4 \times 10^{9} \mathrm{RBCs} / \mathrm{ml} ; 50-\mu 1$ volumes of bacterial suspension were mixed with equal volumes of RBCs in 96-well microtitration plates, and centrifuged at $2200 \mathrm{~g}$ for $10 \mathrm{~min}$ to achieve close contact between bacteria and RBCs. The plates were incubated at either $37^{\circ} \mathrm{C}$ or $4^{\circ} \mathrm{C}$ for $2 \mathrm{~h}$. Pellets were resuspended in cold PBS, centrifuged at $4^{\circ} \mathrm{C}$ for $15 \mathrm{~min}$ and the $\mathrm{OD}_{490}$ of the supernates was measured with an ELISA reader (Titertek-Multiscan, Flow Laboratories).

\section{Plasmid analysis}

Plasmid DNA was isolated by the method of Birnboim and Doly ${ }^{11}$ and electrophoresed in agarose $0.7 \%$ gel. $^{12}$

\section{Tests for bacterial virulence}

Each strain was tested for virulence, both by invasion of $\mathrm{HeLa}$ cell monolayers ${ }^{6}$ and by the Sereny test. ${ }^{13}$ The latter was performed by inoculating $20 \mu \mathrm{l}$ of bacterial suspension containing $3 \times 10^{8} \mathrm{cfu} / \mathrm{ml}$ into the conjunctival sac of an adult guinea-pig; strains producing keratoconjunctivitis within $72 \mathrm{~h}$ were considered virulent.

For the former, non-confluent monolayers of HeLa cells on 12-mm cover glass (Kimble, Toledo, $\mathrm{OH}$, USA) in a vial were inoculated with bacteria, centrifuged for $10 \mathrm{~min}$ at $2200 \mathrm{~g}$ and incubated for $2 \mathrm{~h}$ 
at $37^{\circ} \mathrm{C}$. Non-invasive bacteria were washed off with PBS. Monolayers were fixed in methanol and stained with Giemsa dye, and the percentage of infected cells was determined by light-microscopy. To calculate the average number of viable bacteria in each infected HeLa cell, strains were inoculated on to monolayers of HeLa cells in a vial, centrifuged for $10 \mathrm{~min}$ at $2200 \mathrm{~g}$, incubated for $15 \mathrm{~min}$, washed three times with PBS, covered with $2 \mathrm{ml}$ of Minimum Essential Medium (Gibco) containing gentamicin $200 \mu \mathrm{g} / \mathrm{ml}$, and reincubated for $2 \mathrm{~h}$ at $37^{\circ} \mathrm{C}$, Monolayers were then washed, cells were trypsinised and counted, and finally cells were lysed with a solution of sodium deoxycholate $0.5 \%$ in distilled water. Dilutions of this suspension were plated to count the number of bacteria/vial. The average number of bacteria in each infected HeLa cell in a vial was calculated as follows:

\section{number of viable bacteria \\ number of HeLa cells $\times$ percentage of infected $\mathrm{HeLa}$ cells}

For comparison of the invasiveness of different organisms, the chosen multiplicity of infection was 100 bacteria/HeLa cell. Each strain was tested at least three times; results are presented as the mean from three experiments.

\section{Treatment of erythrocytes}

Erythrocytes (RBCs) were treated at $37^{\circ} \mathrm{C}$ for $1 \mathrm{~h}$ with various reagents (Sigma): $\mathrm{N}$-acetylneuraminic acid $1 \% \mathrm{w} / \mathrm{v}$ (NANA), lysozyme $250 \mu \mathrm{g} / \mathrm{ml}$, neuraminidase 100-1000 U/ml, and lectins - wheat germ agglutinin $10 \mu \mathrm{g} / \mathrm{ml}$, phytohaemagglutinin $1.0 \mu \mathrm{g} / \mathrm{ml}$ and Concanavalin A $0 \cdot 1 \mu \mathrm{g} / \mathrm{ml}$. Higher concentrations of phytohaemagglutinin or Concanavalin A caused lysis of guinea-pig RBCs.

\section{Treatment of bacteria}

Bacteria $\left(10^{9} \mathrm{cfu}\right)$ were treated with: (1) enzymes for $4 \mathrm{~h}$ at $37^{\circ} \mathrm{C}$-trypsin (Flow Laboratories, Herts) $100 \mu \mathrm{g} / \mathrm{ml}$, proteinase K (Sigma) $100 \mu \mathrm{g} / \mathrm{ml}$; (2) rabbit sera for $1 \mathrm{~h}$ at $37^{\circ} \mathrm{C}$-normal serum and homologous and heterologous antisera against whole bacterial cells $;^{14}(3)$ heat, at $56^{\circ} \mathrm{C}$ or $100^{\circ} \mathrm{C}$ for $1 \mathrm{~h}$.

\section{Extraction of bacterial components}

Lipopolysaccharide (LPS) of S. flexneri strain Z$611, S$. dysenteriae type 1 strain Z-24623, and EIEC strain 2 were extracted with hot phenol-water ${ }^{15}$ and purified by ultracentrifugation at $100000 \mathrm{~g}$ for $4 \mathrm{~h}$. Nucleic acid and protein were removed by treatment with DNAase and RNAase, and proteinase K $100 \mu \mathrm{g}$ / $\mathrm{ml}$, respectively. Bacterial cells were depleted of LPS by treating cells with edetic acid. Outer-membrane protein (OMP) was prepared by water extraction. ${ }^{16}$

LPS and OMP were freeze-dried and reconstituted in PBS. Protein was estimated by dye-binding ${ }^{17}$ and carbohydrate in LPS was estimated by the method of Dubois et al. ${ }^{18} \mathrm{CH}$ activity of LPS and OMP was tested at concentrations up to $10 \mathrm{mg} / \mathrm{ml}$. Bacterial cells depleted of OMP and LPS were also assayed for $\mathrm{CH}$ activity.

\section{Results}

\section{Influence of growth medium on $\mathrm{CH}$ activity}

Bacteria were grown with shaking in TSB, CYE and $\mathrm{MM}$, and their $\mathrm{CH}$ activity was assayed with sheep RBCs (fig. 1). For S. flexneri, TSB was the best medium, whereas $S$. dysenteriae and EIEC exhibited maximal activity when grown in CYE; on the other hand, CYE provided only poor $\mathrm{CH}$ activity by $S$. flexneri, $S$. sonnei and $S$. boydii. $\mathrm{CH}$ activity was reduced or undetectable when EIEC and shigellae were grown in static broth or on agar plates of these media.

\section{CH activity on $\mathrm{RBCs}$ of different animal species}

RBCs from guinea-pig, rabbit, rat, mouse, monkey, man (blood group $\mathrm{O}$ ), sheep and chicken were compared (fig. 2). All the bacterial species exhibited maximal $\mathrm{CH}$ activity against guinea-pig RBCs; hence, the latter were used for subsequent experiments. Except with $S$. flexneri and EIEC, sheep RBCs were poorly lysed.

The influence of growth medium was re-tested with guinea-pig RBCs: TSB was the most suitable medium for production of $\mathrm{CH}$ by shigellae and CYE for EIEC (fig. 1).

\section{Influence of $\mathrm{pH}$ of growth medium on $\mathrm{CH}$ activity}

For $S$. flexneri, $S$. dysenteriae type 1 and $S$. sonnei, neutral or slightly alkaline $\mathrm{pH}(\mathbf{7} \cdot 3-8 \cdot 5)$ was suitable for $\mathrm{CH}$ production. However, with $S$. boydii, the activity was reduced as the $\mathrm{pH}$ was increased from $7 \cdot 3$ to $9 \cdot 0$, and there was not much reduction in $\mathrm{CH}$ activity as the $\mathrm{pH}$ decreased from $7 \cdot 3$ to $6 \cdot 0$. EIEC showed a marked optimum at $\mathrm{pH} 7 \cdot 3$, and this $\mathrm{pH}$ was also near the optimal for shigellae (fig. 3).

\section{Influence of duration and temperature of growth on CH activity}

$\mathrm{CH}$ activity was examined in bacterial cultures grown for $4-48 \mathrm{~h}$. It was maximal at $6-10 \mathrm{~h}$, but beyond $24 \mathrm{~h}$ bacteria exhibited little haemolytic activity.

$\mathrm{CH}$ activity of both shigellae and EIEC was greatly dependent on growth temperature: strains which were strongly positive when grown at $37^{\circ} \mathrm{C}$ showed reduced activity when grown at $30^{\circ} \mathrm{C}$. Activity could be partially restored by changing the growth temperature to $37^{\circ} \mathrm{C}$ for $2 \mathrm{~h}$ before incubation with $\mathrm{RBCs}$, but 


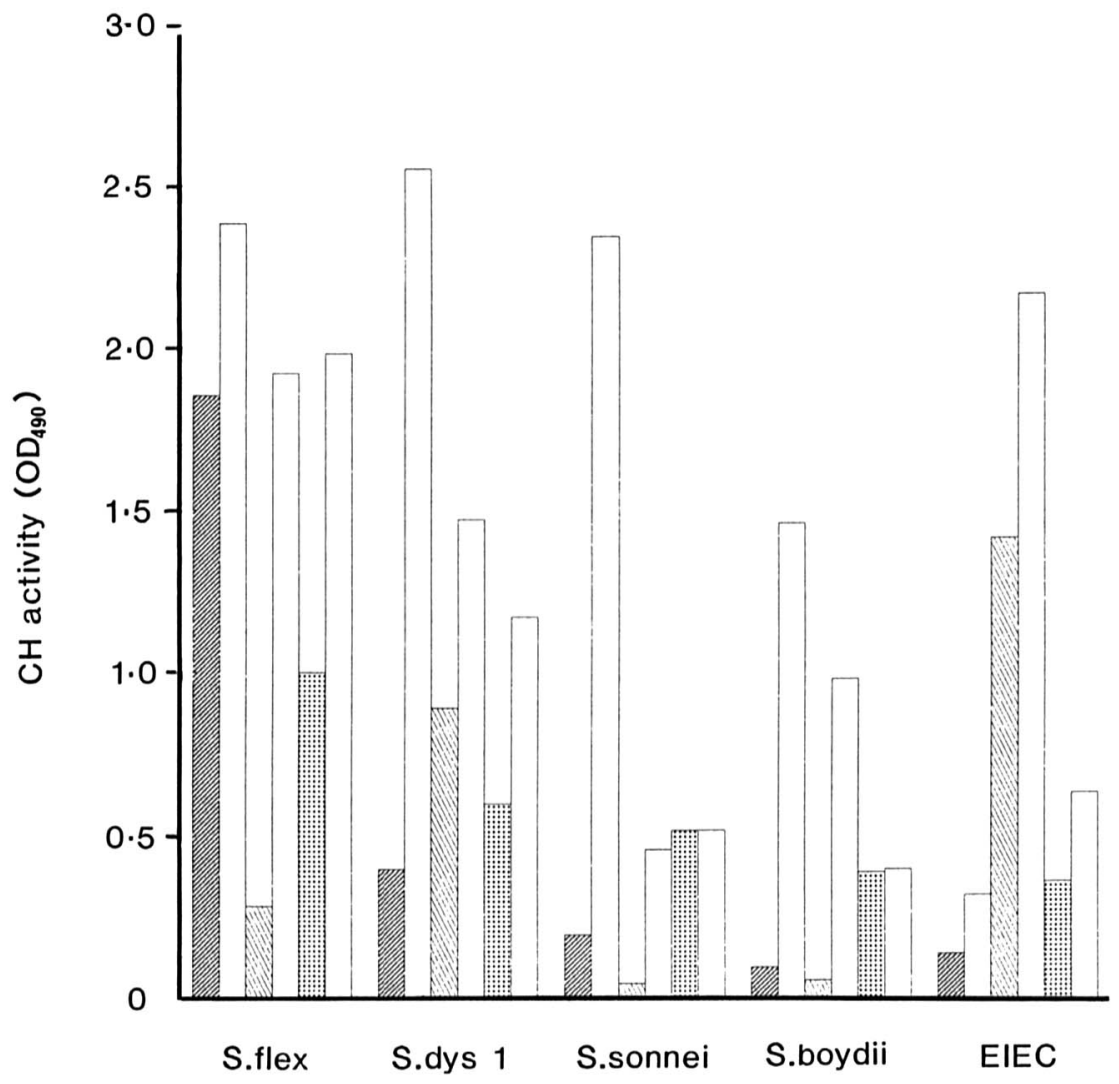

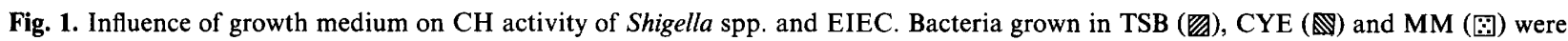
tested with sheep RBC. Blank bars $(\square)$ to the right of the marked bars indicate $\mathrm{CH}$ activity of bacteria grown in the same medium but tested with guinea-pig RBC. $\mathrm{OD}_{490}$ was measured with an ELISA reader. S. flex $=S$. flexneri; $\mathrm{S}$. dys $1=S$. dysenteriae type 1 .

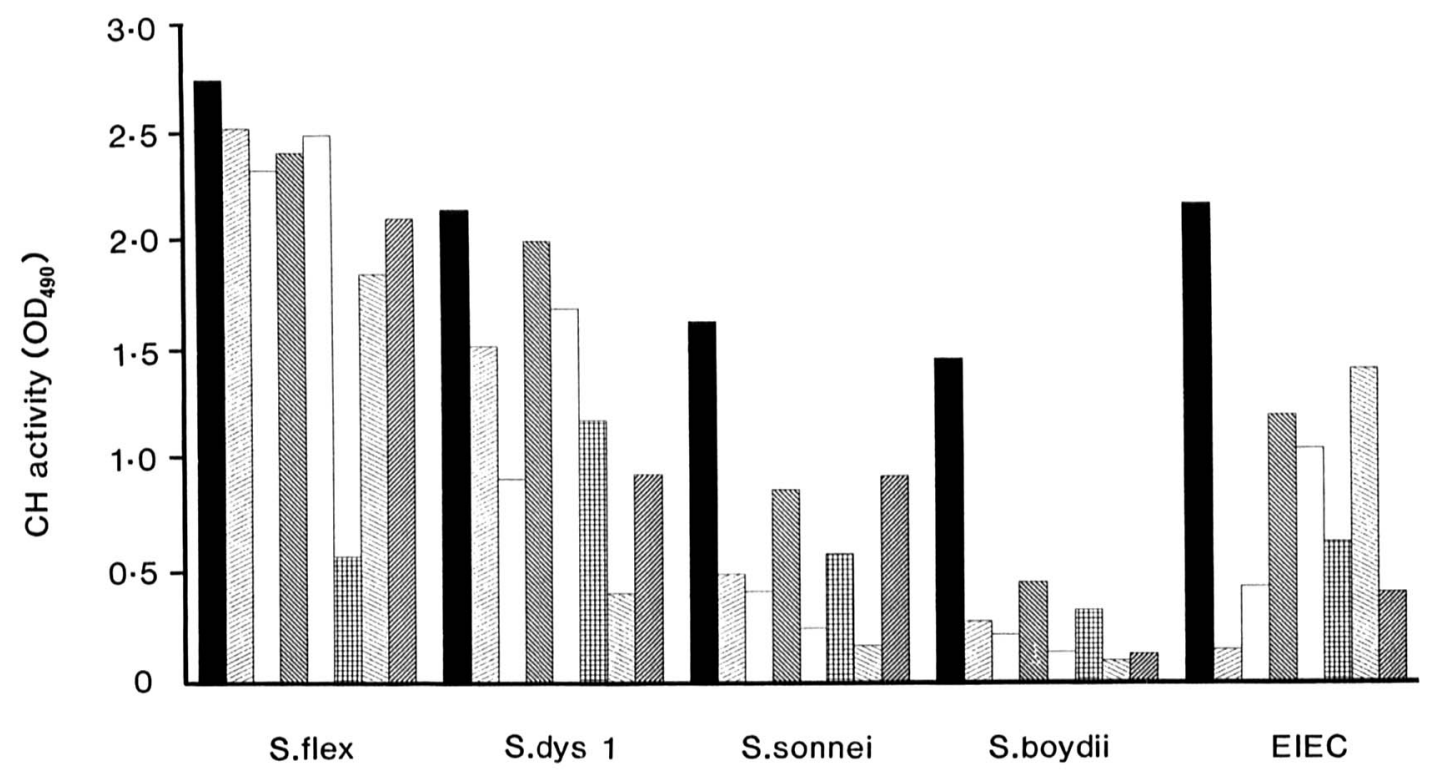

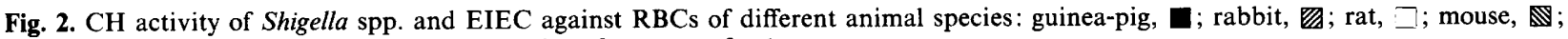

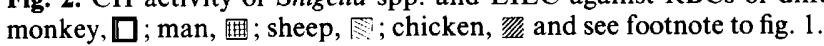

extension of this period to $4 \mathrm{~h}$ did not result in further increase of $\mathrm{CH}$ activity.

No $\mathrm{CH}$ activity was shown when the assay was performed at $4^{\circ} \mathrm{C}$, even with bacteria grown optimally at $37^{\circ} \mathrm{C}$.

\section{Association of large virulence plasmid with $\mathrm{CH}$ activity}

Plasmid profiles of several virulent strains, both shigellae and EIEC, and of their avirulent counterparts 


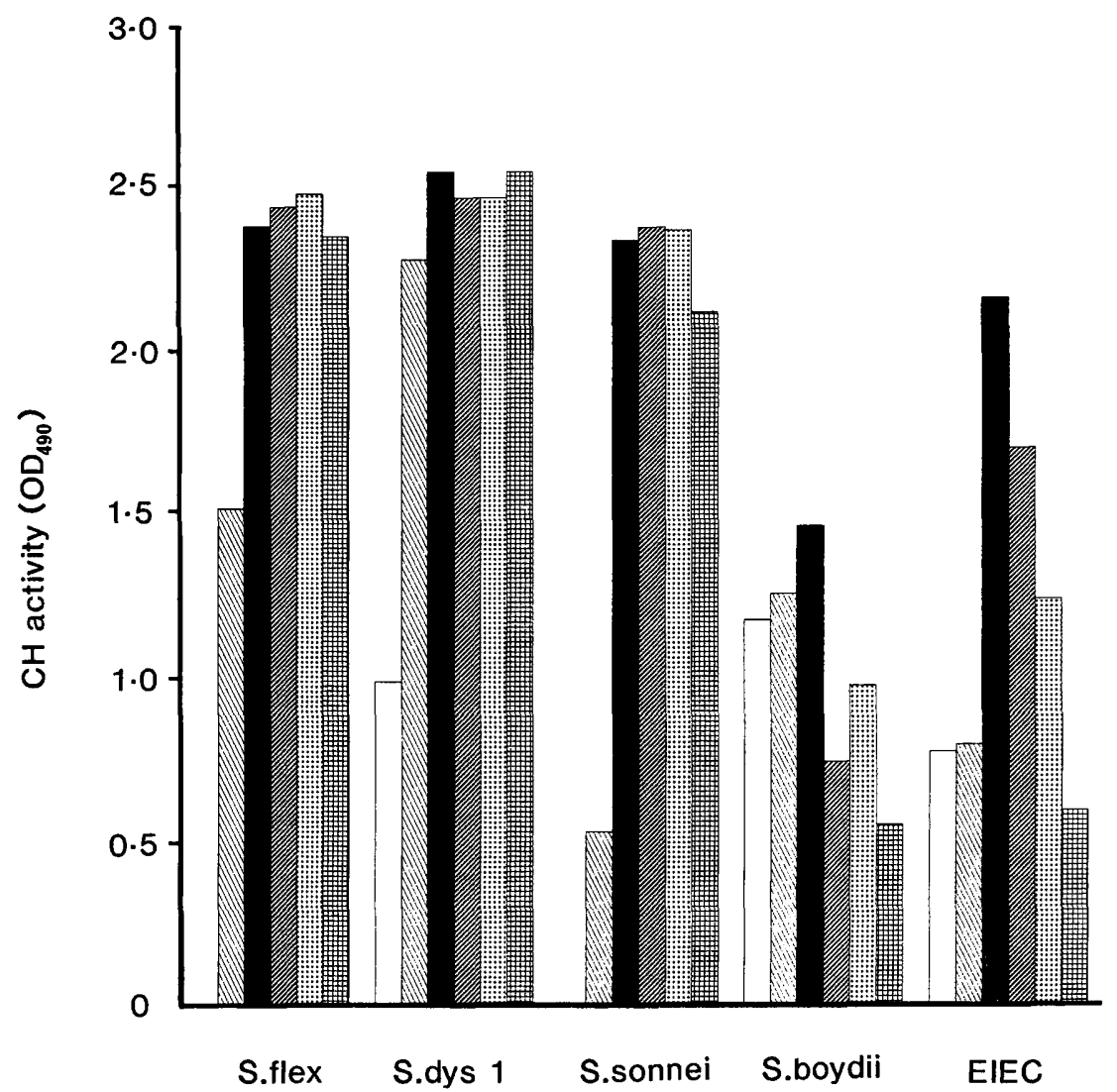

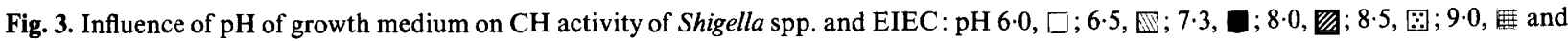
see footnote to fig. 1 .

were analysed to study association of the 120-140Mda plasmid with $\mathrm{CH}$ activity. Avirulence was determined by the inability to bind the dye Congored, ${ }^{19}$ to produce keratoconjunctivitis in the guineapig, ${ }^{13}$ and to invade HeLa cells. ${ }^{6}$ In all the species, $\mathrm{CH}$ activity appeared to be plasmid mediated, because loss of the large plasmid, or reduction in size by deletion, resulted in almost complete absence of $\mathrm{CH}$ activity (table I).

\section{Correlation of $\mathrm{CH}$ activity with invasion potential of bacteria}

$S$. flexneri serotypes $2 \mathrm{a}, 5$ and $\mathrm{Y}, S$. dysenteriae type 1 , and $S$. sonnei showed similar invasion potential after incubation for $2 \mathrm{~h}$, reaching 51-70 bacteria/ HeLa-cell (table I). However, EIEC type O28 showed a much higher degree of invasion (152 bacteria/cell) than shigellae. Other serotypes of EIEC and $S$. flexneri and strains of $S$. boydii showed lower invasion capability (3-27 bacteria/cell).

Generally, $\mathrm{CH}$ activity correlated well with the invasion potential of the organism. However, avirulent strains of $S$. dysenteriae type 1, although non-invasive in HeLa-cell assay, exhibited slightly higher $\mathrm{CH}$ activity than some virulent strains of other Shigella spp. and EIEC. Also, one virulent EIEC strain (O124) exhibited low $\mathrm{CH}$ activity although it was moderately invasive (table I).

\section{Influence of various treatments of $R B C s$ and bacteria on CH activity}

Pre-treatment of RBCs with lysozyme resulted in significant reduction $(56-75 \%)$ in $\mathrm{CH}$ activity, but neuraminidase and NANA had minimal inhibitory effect (table II). Of the three lectins, wheat germ agglutinin showed $50-67 \%$ inhibition of $\mathrm{CH}$ activity, whereas phytohaemagglutinin and Concanavalin A had no effect.

No reduction in $\mathrm{CH}$ activity was noted when bacteria were treated with trypsin, but $\mathrm{CH}$ activity was completely lost after treatment with proteinase $\mathrm{K}$, indicating that the $\mathrm{CH}$ molecule may be a trypsinresistant protein. Significant reduction of $\mathrm{CH}$ activity occurred after incubation of bacteria with homologous antiserum, whereas little or no inhibition was found with heterologous or control serum. Prior heattreatment of cells at $56^{\circ} \mathrm{C}$ for $1 \mathrm{~h}$ resulted in significant reduction in $\mathrm{CH}$ activity, and the activity was completely lost after heating at $100^{\circ} \mathrm{C}$ for $1 \mathrm{~h}$.

\section{CH activity of bacterial components}

The OMP and LPS obtained from $S$. flexneri strain Z-611, S. dysenteriae type 1 strain Z-24623 and EIEC strain 2, either separately or combined, did not haemolyse RBCs in concentrations up to $10 \mathrm{mg} / \mathrm{ml}$ (table II). However, cells depleted of OMP showed 
Table II. Influence of RBC treatment and of bacterial treatment on $\mathrm{CH}$ activity of $S$. dysenteriae type 1, strain Z-24623, S. flexneri strain Z-611 and EIEC strain 2

\begin{tabular}{|c|c|}
\hline Assay material & $\mathrm{CH}$ activity $(\%)^{*}$ \\
\hline \multicolumn{2}{|l|}{ Untreated bacteria and RBCs treated with } \\
\hline lysozyme $250 \mu \mathrm{g} / \mathrm{ml}$ & $25-44$ \\
\hline neuraminidase $100-1000 \mathrm{U} / \mathrm{ml}$ & $85-90$ \\
\hline $\mathrm{N}$-acetyl neuraminic acid $10 \mathrm{mg} / \mathrm{ml}$ & $80-85$ \\
\hline wheat germ agglutinin $1-10 \mu \mathrm{g} / \mathrm{ml}$ & $33-50$ \\
\hline phytohaemagglutinin $0 \cdot 1-1 \cdot 0 \mu \mathrm{g} / \mathrm{ml}$ & 100 \\
\hline Concanavalin A $0.01-0.1 \mu \mathrm{g} / \mathrm{ml}$ & 100 \\
\hline \multicolumn{2}{|l|}{ Untreated RBCs and bacteria treated with } \\
\hline proteinase $\mathrm{K} 100 \mu \mathrm{g} / \mathrm{ml}$ & 0 \\
\hline trypsin $100 \mu \mathrm{g} / \mathrm{ml}$ & 100 \\
\hline \multirow[t]{2}{*}{ homologous rabbit antiserum against $S$. dysenteriae } & 60 \\
\hline & 10 \\
\hline EIEC & 55 \\
\hline antiserum against heterologous bacterial species & $91-100$ \\
\hline normal rabbit antiserum & 100 \\
\hline heat: $56^{\circ} \mathrm{C}$ for $1 \mathrm{~h}$ & 20 \\
\hline $100^{\circ} \mathrm{C}$ for $1 \mathrm{~h}$ & 0 \\
\hline \multicolumn{2}{|l|}{ Untreated RBCs and bacteria depleted of } \\
\hline OMP & $16-30$ \\
\hline LPS & 100 \\
\hline \multicolumn{2}{|l|}{ Untreated RBCs and bacterial components: } \\
\hline OMP $1-10 \mathrm{mg} / \mathrm{ml}$ & 0 \\
\hline & 0 \\
\hline LPS + OMP $10-20 \mathrm{mg} / \mathrm{ml}$ & 0 \\
\hline
\end{tabular}

* Percentage of $\mathrm{CH}$ activity of positive control (untreated bacteria or untreated RBCs).

$70-84 \%$ reduction in $\mathrm{CH}$ activity whereas cells depleted of LPS showed no loss. These results suggest that the $\mathrm{CH}$ molecule may be a component of bacterial outer membrane.

\section{Discussion}

The best medium for demonstrating $\mathrm{CH}$ activity of EIEC was CYE broth (fig. 1); the higher amount of amino acids in this medium compared with the other two media, TSB and MM, may have influenced the $\mathrm{CH}$ activity. ${ }^{20}$ On the other hand, Shigella spp. exhibited maximal $\mathrm{CH}$ activity when grown in TSB. Other studies ${ }^{20,21}$ showed that the capacity of $S$. dysenteriae to agglutinate RBCs, and the adherence of $S$. flexneri type 2a to cultured mammalian cells, were maximal when grown in CYE; but this medium was not appropriate for $\mathrm{CH}$ activity of Shigella spp. However, other investigators ${ }^{6,7}$ found TSB suitable for $\mathrm{CH}$ activity and for invasion of epithelial cells in vitro by shigellae. These varied results probably indicate that the nutritional requirements for the expression of virulence factors by Shigella spp. and EIEC are diverse.

All the bacterial species in the present study showed the highest $\mathrm{CH}$ activity when tested with guinea-pig RBCs (fig. 2), suggesting varied expression of $\mathrm{CH}$ receptor among different animal species. The lower susceptibility of sheep RBCs may explain the absence of $\mathrm{CH}$ activity in $S$. boydii and EIEC as observed by Clerc et al. ${ }^{7}$

In general, $\mathrm{CH}$ production was favoured at slightly alkaline $\mathrm{pH}$ (fig. 3), which was also optimal for growth. The relatively high $\mathrm{CH}$ activity of $S$. boydii at $\mathrm{pH} 6.0$, and the sharp decrease in $\mathrm{CH}$ activity of EIEC at acidic or alkaline $\mathrm{pH}$, indicate that the optimal $\mathrm{pH}$ for bacterial growth and for expression of $\mathrm{CH}$ activity are not the same with all bacteria.

$\mathrm{CH}$ activity was completely destroyed by proteinase $\mathrm{K}$ (table II), indicating its proteinaceous nature; but it was insensitive to trypsin. This may be because proteinase $\mathrm{K}$ is a mixture of endopeptidase and exopeptidase including carboxypeptidases and aminopeptidases with non-specific protease activity, whereas trypsin is highly selective in action, cleaving only those peptide bonds whose carboxyl function is donated by either a lysine or an arginine molecule. ${ }^{22}$ Thus, resistance to trypsin does not disprove that $\mathrm{CH}$ might be a protein molecule.

Reduction in $\mathrm{CH}$ activity by pre-treatment of the bacteria with homologous antisera, and minimal inhibition with heterologous antisera, indicate the probable cell-surface location of the $\mathrm{CH}$ molecule which is also antigenic.

Bacteria depleted of OMP, but not those depleted of LPS, showed significant decrease in $\mathrm{CH}$ activity, indicating its outer membrane location. On the other hand, isolated OMP and LPS, either separately or together, failed to show $\mathrm{CH}$ activity. If it is assumed that $\mathrm{CH}$ is a protein in the outer membrane, then inability of the isolated OMP to cause haemolysis needs to be explained. Live metabolically active bacteria are necessary for invasion $;{ }^{2}$ we also observed that cells from the logarithmic phase of growth were more efficient in $\mathrm{CH}$ assay than cells from the 
stationary phase, and little $\mathrm{CH}$ activity was detected when bacteria were either incubated with $\mathrm{RBCs}$ at $4^{\circ} \mathrm{C}$ or pre-heated at $56^{\circ} \mathrm{C}$ for $1 \mathrm{~h}$. Thus, isolated cell components which include a relevant molecule may be non-functional in the absence of metabolically active bacteria.

Decrease in $\mathrm{CH}$ activity after treatment of RBCs with lysozyme suggests that the $\mathrm{CH}$ molecule interacts with a lysozyme-sensitive moiety on the RBC surface. Treatment with wheat germ agglutinin, specific for the lysozyme substrate of $\mathrm{N}$-acetyl-D-glucosamine oligomers of three units in length $\left(N, N^{\prime}, N^{\prime \prime}\right.$-triacetylchitotriose), ${ }^{23}$ also caused significant reduction in $\mathrm{CH}$ activity. On the other hand, treatment with phytohaemagglutinin and Concanavalin $\mathrm{A}$, which do not interact with the lysozyme substrate chitotriose, failed to reduce $\mathrm{CH}$ activity. The minimal inhibitory effect of neuraminidase and NANA on $\mathrm{CH}$ activity, probably by non-specific interaction, renders the involvement of sialic acid unlikely. All this evidence suggests a chitotriose-like moiety as the probable receptor for CH.

Studies with bacteria harbouring an intact plasmid and a modified plasmid, and with plasmidless derivatives, showed a correlation between $\mathrm{CH}$ activity and HeLa cell invasiveness. ${ }^{6}$ Similar results were obtained in the present study, with two exceptions (table I): avirulent $S$. dysenteriae type 1 strains had relatively high $\mathrm{CH}$ activity but were non-invasive, and virulent EIEC (O124) had low $\mathrm{CH}$ activity but was invasive. The reason for this lack of correlation is not apparent; but it is noticeable that, within each species, virulent strains always had higher $\mathrm{CH}$ activity and invasion potential than their avirulent counterparts. Our results showed that certain EIEC strains, especially O28, were even more invasive than those of $S$. flexneri and $S$. dysenteriae, and $S$. boydii was moderately invasive.

\section{References}

1. Formal SB, Hale TL, Sansonetti PJ. Invasive enteric pathogens. Rev Infect Dis 1983; 5: S702-S707.

2. Hale TL, Bonventre PF. Shigella infection of Henle intestinal epithelial cells: role of the bacterium. Infect Immun 1979, 24: 879-886

3. Maurelli AT, Sansonetti PJ. Identification of a chromosomal gene controlling temperature-regulated expression of Shigella virulence. Proc Natl Acad Sci USA 1988; 85: 28202824.

4. Levine MM, Nataro JP, Karch $\mathbf{H}$ et al. The diarrheal response of humans to some classic serotypes of enteropathogenic Escherichia coli is dependent on a plasmid encoding an enteroinvasiveness factor. J Infect Dis 1985; 152: 550-559.

5. Hale TL, Oaks EV, Formal SB. Identification and antigenic characterization of virulence-associated, plasmid-coded proteins of Shigella spp. and enteroinvasive Escherichia coli. Infect Immun 1985; 50: 620-629.

6. Sansonetti PJ, Ryter A, Clerc P, Maurelli AT, Mounier J. Multiplication of Shigella flexneri within HeLa cells: lysis of the phagocytic vacuole and plasmid-mediated contact hemolysis. Infect Immun 1986; 51 : 461-469.

7. Clerc P, Baudry B, Sansonetti PJ. Plasmid-mediated contact haemolytic activity in Shigella species: correlation with penetration into HeLa cells. Ann Inst Pasteur Microbiol $1986 ; 137 \mathrm{~A}: 267-278$
Other investigators also reported the invasive nature of EIEC in HEp-2 cells. ${ }^{24,25}$ EIEC (O28) has also been found to possess high cell-surface hydrophobicity, similar to $S$. dysenteriae type 1 (unpublished observation). The absence of $\mathrm{CH}$ activity in EIEC and $S$. boydii noted by Clerc et al. ${ }^{7}$ could be due to their use of sheep RBCs (see above) or of different strains of bacteria.

Reduced $\mathrm{CH}$ activity by bacterial cells grown at $30^{\circ} \mathrm{C}$, and partial restoration after changing from $30^{\circ} \mathrm{C}$ to $37^{\circ} \mathrm{C}$, indicate that the activity might be thermoregulated, as are other virulence properties of Shigella spp. - invasion of epithelial cells in vitro, ${ }^{6,7}$ expression of peptides involved in invasion, ${ }^{5}$ binding of the dye Congo red, ${ }^{19}$ and haemagglutination. ${ }^{20}$ The $\mathrm{CH}$ activity in $S$. flexneri has been shown to be critical for lysis of the phagocytic vacuole after invasion of HeLa cells, which permits efficient intracellular multiplication. ${ }^{6}$ In this study, we have demonstrated $\mathrm{CH}$ activity and invasion of HeLa cells by EIEC; it is possible that $\mathrm{CH}$ activity of EIEC may also be essential for intracellular multiplication.

This research was supported by the International Centre for Diarrhoeal Disease Research, Bangladesh, which is supported by countries and agencies that share its concern about the impact of diarrhoeal diseases in the developing countries. Current major donors are: The Aga Khan Foundation, Arab Gulf Fund, Australia, Bangladesh, Belgium, Canadian International Development Agency, Canadian International Development Research Centre, Danish International Development Agency, France, the Ford Foundation, Japan, the Netherlands, Norwegian Agency for International Development, Sweden, Swiss Development Cooperation, United Kingdom, United Nations Development Programme, United Nations Children's Fund, United Nations Capital Development Fund, United States Agency for International Development, World Health Organization and World University Service of Canada.

We thank Dr F. Qadri for LPS of S. flexneri strain Z-611 and rabbit antiserum raised against this strain, and $\mathrm{Mr} \mathrm{M}$. Haque for secretarial assistance.

8. Sansonetti PJ, D'Hauleville H, Ecobichon C, Pourcel C Molecular comparison of virulence plasmids in Shigella and enteroinvasive Escherichia coli. Ann Microbiol (Inst Pasteur) 1983; 134A : 295-318.

9. Pál T, Pácsa S, Emödy L, Vörös S. Antigenic relationship among virulent enteroinvasive Escherichia coli, Shigella flexneri, and Shigella sonnei detected by ELISA. Lancet $1983 ; 2: 102$.

10. Ahmed ZU, Sarker MR, Sack DA. Nutritional requirements of shigellae for growth in a minimal medium. Infect Immun $1988 ; 56: 1007-1009$

11. Birnboim HC, Doly J. A rapid alkaline extraction procedure for screening recombinant plasmid DNA. Nucleic Acids Res 1979; 7 : 1513-1523.

12. Meyers JA, Sanchez D, Elwell LP, Falkow S. Simple agarose gel electrophoretic method for the identification and characterization of plasmid deoxyribonucleic acid. $J$ Bacteriol 1976; 127: 1529-1537.

13. Sereny B. Experimental Shigella keratoconjunctivitis. Acta Microbiol Hung 1955; 2: 293-296.

14. Haider K, Azad AK, Qadri F, Nahar S, Ciznar I. Role of plasmids in virulence-associated attributes and in $\mathrm{O}$ antigen expression in Shigella dysenteriae type 1 strains. $J$ Med Microbiol 1990; 33: 1-9.

15. Westphal O, Jann K. Bacterial lipopolysaccharides: extraction with phenol-water and further applications of the procedure. In: Whistler RL (ed) General polysaccharides (Methods of carbohydrate chemistry, No. 5). New York, Academic Press. 1965: 83-91. 
16. Oaks EV, Hale TL, Formal SB. Serum immune response to Shigella protein antigens in Rhesus monkeys and humans infected with Shigella spp. Infect Immun 1986; 53: 57-63.

17. Bradford MM. A rapid and sensitive method for the quantitation of microgram quantities of protein utilizing the principle of protein-dye binding. Anal Biochem 1976; 72 : 248-254.

18. Dubois M, Gilles KA, Hamilton JK, Rebers PA, Smith F. Colorimetric method for determination of sugars and related substances. Anal Chem 1956; 28 : 350-356.

19. Qadri F, Hossain SA, Čižnár I et al. Congo red binding and salt aggregation as indicators of virulence in Shigella species. $J$ Clin Microbiol 1988; 26: 1343-1348.

20. Qadri F, Haq S, Čižnár I. Hemagglutinating properties of Shigella dysenteriae type 1 and other Shigella species. Infect Immun 1989; 57: 2909-2911.

21. Izhar M, Nuchamowitz Y, Mirelman D. Adherence of Shigella flexneri to guinea pig intestinal cells is mediated by a mucosal adhesin. Infect Immun 1982; 35: 1110-1118.

22. Lehninger AL. Biochemistry; the molecular basis of cell structure and function. New York, Worth Publishers, Inc. 1975: 1104.

23. Keusch GT, Jacewicz M. Pathogenesis of Shigella diarrhea VII. Evidence for a cell membrane toxin receptor involving $\beta 1 \rightarrow 4$-linked N-acetyl-D-glucosamine oligomers. $J$ Exp Med $1977 ; 146 ; 535-546$.

24. Small PLC, Isberg RR, Falkow S. Comparison of the ability of enteroinvasive Escherichia coli, Salmonella typhimurium, Yersinia pseudotuberculosis and Yersinia enterocolitica to enter and replicate within HEp-2 cells. Infect Immun 1987; 55: 1674-1679.

25. Falkow S, Small P, Isberg R, Hayes SF, Corwin D. A molecular strategy for the study of bacterial invasion. Rev Infect Dis 1987; 9 Suppl: S450-S455. 